\title{
KOKORO TO KOKORO NO KANKEI: MALAYSIA'S RESPONSE TO THE AFTERMATH OF THE JAPANESE EARTHQUAKE AND TSUNAMI ${ }^{1}$
}

\author{
Asmadi Hassan, Rohayati Paidi, Md Nasrudin Md Akhir, \\ Mohd Ikbal Mohd Huda
}

\section{Introduction}

An earthquake of magnitude nine on the Richter scale accompanied by a tsunami of gigantic proportions struck the Tohoku region due to a radiation leak at the Fukushima Daiichi nuclear power plant on March 11, 2011. Suffice to say, huge losses of property as well as thousands of lives were lost. An estimated 1.2 million household experienced loss of electricity while 1.4 million homes encountered a disruption of water supply, 20,000 people died or disappeared, and the destruction area was in excess of $600 \mathrm{sq}$ $\mathrm{km} .{ }^{2}$ Residents were ordered to relocate with the Japanese government providing 2,500 evacuation centers for the victims including in schools and public halls. What was Malaysia's response after the disaster since Japan is always described as a very close friend? This article analyzes the reaction of the government and people of Malaysia after the tragedy as proof of Japan`s influence to Malaysia and vice-versa as a friend in need and hence a friend indeed, friends in happier times or times of hardship, this special bond which can be termed a heart-to-heart relationship (kokoro to kokoro no kankei).

This article is divided into three parts: the first is to analyze the responses from Malaysia, particularly at the government and societal level. Second is to evaluate the reaction and responses of the Japanese after receiving aid, and third to assess why kokoro to kokoro no kankei is important in bilateral relations. Most researchers argue that the long term relationship in terms of economy, politics and social relations between the two countries is a major factor as to why Malaysians were willing to lend a hand to the people of Japan. Besides, Japan is considered very close to Malaysians considering the very many aspects of life from home appliances extending to the influence of Japanese soft power in the form of anime series amongst other things. Such feelings are translated into the general willingness of Malaysians as a whole to lend every assistance from financial and humanitarian aid to prove the existance of kokoro to kokoro no kankei.

\footnotetext{
1 The authors thank the Japan Foundation Research Grant for sponsoring this research.

2 “BSMM Serah Baki Dana Tabung Bencana Jepun", Harian Metro, 21 Mei 2012.
} 


\section{Response of Malaysia: Government Level}

After the tsunami and earthquake struck Japan, immediate action was taken by Prime Minister Najib Razak who swiftly ordered search and rescue teams, medical officers and sniffer dogs to be sent to Japan for search and rescue missions. In cases like this the "Special Malaysia Disaster Assistance and Rescue Team" (SMART) is always sent to the disaster site. Although SMART could not be of assistance eventually, but the quick action by the Malaysian government to offer assistance reflected the close ties between the two governments. ${ }^{3}$ Close friendship between the two countries was apparent when on March 17, 2011 in a press conference at the Japanese Embassy Kuala Lumpur, Foreign Minister Anifah Aman expressed sympathy and extended condolences to Japanese government. Anifah Aman as well as his Deputy Minister A. Kohilan Pillay and senior officials from the Ministry of Foreign Affairs Malaysia also signed the condolence message on behalf of the government of Malaysia.

On March 17, 2011, a "Motion on Condolence Message and Sympathy to the Government and people of Japan," was brought to the Japanese House of Representatives. These messsages showed deep sympathy from the people of Malaysia to the victims in Japan. ${ }^{4}$ Furthermore, for such messages to be brought to the House of Representatives, the top most tier in the administrative system, reflected the importance of MalaysiaJapan friendship. In line with the significant relationship, the government launched Tabung Bencana Kementerian luar Negeri (Foreign Ministry Disaster Fund, TBKLN) on March 21, 2011 with the aim of raising funds and easing the suffering of Japanese victims. Through the fund, Malaysians who sympathized with the victims could channel financial contributions and tax exemptions were given for these contributions. On March 29, 2011 the Japanese embassy launched a ceremony commemorating the victims of the earthquake and tsunami. Present at the ceremomy were namely speaker of the House of Councillor, Abu Zahar Ujang, foreign ambassadors in Kuala Lumpur, Japan-related organizations and NGOs, overall the presence of 260 people indicated overwhelming support for Japan. ${ }^{5}$

Former Prime Minister, Dr. Mahathir also expressed his condolences to the people of Japan through The Japan Times and expressed his belief in their strength of character and will to rebuild the ruined cities and towns. He was also moved by the reaction of the Malaysian government in offering every effort to help the victims in Japan. ${ }^{6}$ In addition, the Perak Royal Prince, Raja Nazrin also offered words of encouragement to the people of Japan citing their remarkably strong will and grit in the face of disaster and misfortune. As the patron and representative of the Yayasan Sultan Azlan Shah and the Perak state government respectively, the prince donated RM200,000 to the victims.

3 On Mac 13, 2011, 15 SMART members with several doctors and medical assistants were instructed to be sent to Japan in order to assist in search and resque work. However, Malaysia's Foreign Minister Anifah Aman insisted that the aid shipment was subject to the Standard Operating Prosedures (SOP) of Japan. The Japanese government did not refuse the assistant from the team but uncertaint situation caused made it difficult to provide a helicopter for the rescue team to be sent to the disaster area. Refer to "Jepun tidak Tolak Bantuan Smart", Utusan Malaysia, 21 Mac 2011.

4 Ili Liyana Mokhtar, "Our message to a Friend", New Straits Times, 18 Mac 2011.

5 東日本大震災 追悼・復興レセプション 日本大使公邸で開催,南国新聞2012年4月 5 日号掲載.

6 "Mahathir Express Condolences to Japan", The Japan Times, 21 Mac 2011.

7 “Japanese Spirit Hailed", New Straits Times, 28 Mac 2011. 


\section{Malaysian Associations and Societies}

Several associations and organizations also responded to the government's call to give immediate aid to help victims in Japan. These organizations launched fundraising activities, joined humanitarian aid team to deliver food, medicine and other necessities, and trauma recovery programs for those living in temporary evacuation centers. The involvement in the relief activities and fundraising was not only participated by any solitary organization, but all Malaysians across the country. This reflected a willingness of all Malaysians to help their fellow friends in Japan. The first organization to help the victims was the Persatuan Pandu Puteri Malaysia (Girl Guides Association Malaysia) which launched the Girl Guides Disaster Fund-Maybank-The Star Disaster Fund on March 18,2011 . The fund began with a contribution of RM200,000 from the YTL Corporation and Maybank respectively. ${ }^{8}$ The fundraising activities then expanded throughout the whole country through members of associations, including schools. In addition, corporate contributions were also channeled through the fund established by the Girl Guides Association Malaysia.

Fundraising activities in Negeri Sembilan was conducted by the Girl Guides Association Malaysia of Negeri Sembilan (PPPMNS). The initiative was a follow through from the Disaster Fund Guides-Maybank-The Star launched on March 18, 2011. PPPMNS prepared 200 donation boxes and circulated them to schools and shopping complexes in Negeri Sembilan. ${ }^{9}$ On the first day of its launch, PPPMNS managed to raise RM50,000 which was a donation by the Patron of the Association, Tunku Ampuan Besar Negri Sembilan Tuanku Aishah Tengku Besar Mahmud. ${ }^{10}$ Besides PPPMNS, other Girl Guides Association throughout Malaysia namely the Tawau branch, Sarawak, Kelantan, Kedah, Terengganu, Putrajaya, Pahang, Pulau Pinang, Kuala Lumpur, Melaka and Selangor also launched their own fundraising activities for those affected by the tragedies. Girl Guides Association Malaysia of Tawau branch for example raised RM9,668 from public contributions within the surrounding areas. ${ }^{11}$ Meanwhile, the Girl Guides Association of the Sarawak branch conducted fund raising activities in 140 schools within the state. In Kelantan, The Lend A Hand Fund for the Japan Earthquake Victims was launched at Sekolah Kebangsaan Kampung Laut in Tumpat where donation boxes were distributed to five districts namely Kota Bharu, Pasir Mas, Tumpat, Pasir Puteh and Machang. Kedah Girl Guides Association branch hold a special fundraising dinner at Awana Porto Malai Langkawi as well as fundraising activities in schools and shopping complexes. ${ }^{12}$ Sultan of Kedah, Sultan Abdul Halim Mu'adzam Shah and wife, Sultanah Tuanku Haminah Hamidun also attended the fundraising activities which successfully raised RM35,000. ${ }^{13}$ In the meantime the Terengganu branch of the Girl Guides Association Malaysia collected RM40,000 via the distribution of 150 donation boxes to schools and government agencies. ${ }^{14}$ Girl Guides Putrajaya, Pahang and Johor also distributed

\footnotetext{
8 "Girl Guides Launch Fund to Help Victims of Twin Disasters", The Star, 19 Mac 2011; "Rosmah Lancar Tabung Bencana Pandu Puteri Bantu Mangsa Tsunami", Berita Harian, 18 Mac 2011.

9 "PPPMCNS Bantu Rakyat Jepun", Utusan Malaysia, 13 April 2011.

10 Chitra S. Nathan, "Girl Guides Raise RM50,000 for Japan Tsunami Victim", The Star, 14 April 2011.

11 "RM9668 Untuk Tabung Tsunami", Utusan Malaysia, 14 April 2011.

12 "Sarawak Girl Guides Play Their Part for Japan", The Star, 20 April 2011.

13 “Kedah's Girl Guides raise RM35,000", The Star, 16 April 2011.

14 “Terengganu Girl Guides Raise RM40,000 for Japan", The Star, 15 April 2011.
} 
donation box throughout the states. ${ }^{15}$ The Girl Guides Pahang for example collected RM50,000 within a week. ${ }^{16}$

Zooming in on fundraising activities in Penang; a total of 22 schools in Seberang Perai Utara mobilized the association members to raise funds for Japanese victims. They were given 200 donation boxes and started mobilizing their staff to schools and shopping complexes. Among the participating schools were the Sekolah Kebangsaan Kampung Selamat, Sekolah Kebangsaan Jalan Hamilton Batu Lanchang, Sekolah Menengah Jenis Kebangsaan Cina Union, Sekolah Tinggi Bukit Mertajam dan Sekolah Jenis Kebangsaan Cina Union. Students directly participating in the fundraising initiative expressed their sympathy for the victims and were determined to help even a little. One of the students said that "I will do my very best to convince my schoolmates to donate generously." 17 A student from Sekolah Kebangsaan Jalan Hamilton Batu Lanchang, S. Shavika donated all of her savings amounting to RM100 to the victims showing her sympathy for the victims. ${ }^{18}$ Sekolah Menengah Jenis Kebangsaan Cina Union with 1,300-strong students ${ }^{19}$ and Sekolah Tinggi Bukit Mertajam also made donations to the disaster fund initiated by the Girl Guides. As a result of these efforts, in April 2011, Girl Guides of Penang managed to raise RM65,603.57. ${ }^{20}$ The donations encompassed all walks of life in the island state as indigenous people living in Lata Kinjang were also not left behind as some of the association members also originate from the village. ${ }^{21}$

Besides the fundraising actvities driven by members of the Girl Guides, The Girl Guides Disaster Fund-Maybank-The Star was also entrusted with the task of handling donations from corporate and other organizations. For example a sum of RM2,497.05 from fundraising activities conducted by Engineering Campus, Universiti Sains Malaysia was channeled to The Girl Guides Disaster Fund-Maybank-The Star. Although the students were not able to directly participate in on-site activities to help the victims in Japan, they were of high hopes that the donations can help ease the burden. Teachers College Pulau Pinang also channeled RM1,896 to the The Girl Guides Disaster Fund following a donation drive in the collage. ${ }^{22}$ The Jean Gan Academy of Ballet and Music also donated RM10,000 to the victims ${ }^{23}$ while Badan Amal dan Kebajikan Tenaga Isteri-Isteri (BAKTI) which actively solicited donations from corporate organizations contributed RM100,000. ${ }^{24}$

The Golden Sands Resort in Penang assisted those affected by donating entire monthly collections to disaster victims through the The Girl Guides Disaster Fund. The resort diversified their efforts to raise funds such as placing the donation boxes at reception counters as well as in the various offices for the staff to make donations. In

15 “Team Raises Funds from 21 Schools", The Star, 14 April 2011.

16 "RM300,000 Collected So Far", The Star, 28 March 2011; "More than 100 Johor Schools Raise Funds for Japan", The Star, 4 April 2011.

17 "Girl Guides, Brownies and Rangers Help Out", The Star, 31 March 2011.

18 "Pupil Gives RM100 Savings to Disaster Victims", The Star, 2 April 2011.

19 Fong Kee Soon, "SMJK Union Students Show their Generosity”, The Star, 29 March 2011.

20 "Guides from Penang Rake in RM65,000", The Star, 18 April 2011.

21 Edmund Ngo, Wong Pek Mei, “Orang Asli Pitch in for Victims”, The Star, 7 April 2011.

22 Kow Kwan Yee, "USM Student", The Star, 14 April 2011; "Raising Funds on Campus for Japan", The Star, 25 Mac 2011.

23 “Dance Academy Donates RM10,000", The Star, 2 April 2011.

24 “BAKTI Derma RM100,000 kepada Mangsa Gempa, Tsunami Jepun”, Berita Harian, 30 Mac 2011. 
order to generate funds for the victims, there was also a garage sale festival for the guests and the public alike to participate. Charity dinners were also held at three hotels owned by the Shangri-La group, the Rasa Sayang Resort and Spa, Golden Sands Resort and Traders Hotel. Tables for the fundraising dinner were categorized as "silver", "gold" and "platinum" in which the price of each was as follows: RM4,000 for silver, RM6,000 for gold and RM8,000 for platinum. Throughout the years the Golden Sands Resort Penang has seen a steady flow of Japanese customers and the awareness to raise funds arose as a token of goodwill and supportive relationship between the establishment and its patrons. ${ }^{25}$

On April 17, 2011, when they ended the donation drive, the association managed to collect RM1.8 million and an official handover ceremony took place with the President of the Girl Guides Association of Malaysia, Rosmah Mansor handing the funds to the then Japan ambassador to Malaysia Masahiko Horie which was subsequently channeled to the Japanese Red Cross (JRC). ${ }^{26}$ Masahiko expressed his admiration following the great efforts of the association and its members to collect a considerable sum within one month. ${ }^{27}$ Even after the fund was officially closed, contributions still poured in totalling up to RM2.166 million. ${ }^{28}$

Another organization which was seriously involved in relief work is Malaysia Relief Agency (MRA). Previous relief work by the agency include the initiatives in Padang, Indonesia, Pakistan as well as in Kedah, Kelantan and Johor. ${ }^{29}$ In Japan, the MRA was involved in the delivery of cooked meals. For example, on April 13, more than four tons of cooked meals were distributed by the MRA in Miyagi Prefecture where 165,000 people were still held up in evacuation centers. ${ }^{30}$ MRA also focused on trauma recovery efforts especially for the elderly and children. They conducted talks, plays, painting sessions and so on. In order to obtain accurate information and establish a systematic delivery service, MRA signed agreements with several Japanese NGOs such as the Japan Islamic Trust, Osaka Mosque, the Mosque of Sendai and Post Care Justice Ummah. ${ }^{31}$ MRA also worked with the Alumni Look East Policy (ALEPS) and Japanese non-governmental organizations for relief activities. For example ALEPS members fluent in Japanese volunteered to be sent to disaster areas to listen and understand the problems faced by victims such as the lack of appropriate residence and places to live. ALEPS also tried to ease the burden by doing volunteer work such as clearing of land to grow vegetables. ALEPS described their contribution as miniscule compared to what the Japanese did for them while they were studying in Japan.

Another notable effort is the cooperation between The New Straits Times Press (M) Bhd, (NSTP) and Media Prima Bhd, which launched a fund known as the NSTPMedia Prima Disaster Fund in collaboration with the Malaysian Red Crescent (MRC). ${ }^{32}$ All contributions made to this fund were awarded tax exemption. Apart from being the

\footnotetext{
25 Winnie Yeoh, "Resort to Raise Funds by Holding Garage Sale and Dinner this Month", The Star, 9 April 2011.

26 “Bantuan RM1.8j Untuk Mangsa Bencana di Jepun”, Utusan Malaysia, 21 April 2011.

27 Ibid.,

28 "Girl Guides Disaster Fund Makes it into Record Book", The Star, 1 Jun 2011.

29 "MRA Gerak Usaha Bantu Mangsa Bencana Jepun", Utusan Malaysia, 28 Mac 2011.

30 "Bantuan Makanan MRA Sampai di Jepun - Shahrulazilan", Utusan Malaysia, 14 April 2011.

31 "MRA, NGO Jepun Jalin Kerjasama", Utusan Malaysia, 16 April 2011.

32 "Kumpulan NSTP, Media Prima Lancar Tabung", Berita Harian, 13 March 2011.
} 
financial trustee, the MRC activities included delivery of basic needs, search and rescue missions, as well as rehabilitation and reconstruction works in disaster affected areas.

On March 21, the MRC received RM918,000 from Tan Chong Sdn Bhd, which was utilized for humanitarian relief efforts in Japan. In the meantime Hard Rock Hotel Penang managed to raise RM25,000 for the victims in Japan..$^{33}$ The money was collected from the hotel charity program, Unite for Japan which was held from 18 March to 21 April 2011. ${ }^{34}$ On March 28 Raja Nazrin handed over RM687,000 donated by the government of Perak (RM100,000), Yayasan Sultan Azlan Shah (RM100,000), Sunway City Bhd (RM100,000), Kuala Lumpur Kepong Bhd (RM100,000), Perak UMNO (RM50,000), Perak Turf Club (RM50,000) and personal contributions by TSH Resources Bhd chairman, Kelvin Tan Aik Pen (RM50,000). ${ }^{35}$ MRC also received corporate donations from Western Digital Sdn Bhd (RM60,209), Southern Lion Sdn Bhd (RM50,000) and Taiko Marketing Sdn Bhd (RM10,000). On March 31 the MRC received a RM500,000 contribution from UMW Toyota Limited. ${ }^{36}$ Between March 20 to April 30,2011, Sushi King channeled $1 \%$ of its total sales to the MRC and the International Tsunami Relief Fund. While the Japanese restaurant chain, Sushi Tei Malaysia contributed $50 \%$ of its sales on March 25, 2011, to the victims. ${ }^{37}$ 7-Eleven Inc., Bermaz Motor Co., Ltd., Pan Malaysian Pools Sdn Bhd, Lim Kok Wing University of Creative Technology, Eu Yan Sang Sdn Bhd, SP Setia Berhad, Selangor Turf Club, Penang Turf Club and Totalisator Board of Malaysia also contributed from RM100,000 to RM300,000. ${ }^{38}$ The Malaysian National Committee and Alumni of the International Association of Traffic and Safety Sciences (IATSS) and Ajinomoto (M) Berhad also donated RM4,000 ${ }^{39}$ and RM10, $000^{40}$ respectively to the NSTP-Media Prima Disaster Fund. The IATSS forum is a training institute established in 1985 through a grant from the founder of Honda Motor Co. Private. Ltd, Soichiro Honda and Takeo Fujisawa for nurturing young leaders from all over the world.

Hotel Equatorial Malaysia also initiated fundraising activites for the tsunami victims in Japan. Kampachi restaurant owned by the hotel donated all of the sales proceeds of one day to the MRC. Similar campaigns were also carried out by a branch of the restaurant in Pavilion Kuala Lumpur as well as at Hotel Equatorial Penang. Hotel Equatorial Kuala Lumpur employees invested time and energy in several efforts namely baking a cake for charity sale at Etoile Bistro, car wash sessions and a donation of RM1 for every room occupied. Consequently funds collected totalled up to RM63,496. ${ }^{41} \mathrm{Low}$ Yat Group launched a Help Japan 2011 campaign in which one of the activities was a two days bazaar involving 45 shops displaying various items ranging from fashion, accessories, food, home furnishings to football game. A blood donation initiative was also held. The funds collected was then channeled to the NSTP-Media Prima and MRC Disaster Fund. ${ }^{42}$ Other establishments like the Eastin Hotel and Groupon Malaysia

\footnotetext{
"Hard Rock Penang Does its Part For Victim", New Strait Times, 23 March 2011.

"Hotel Hard Rock Derma RM25,000", Utusan Malaysia, 24 May 2011.

"Japanese Spirit Hailed", New Straits Times, 28 March 2011.

"BSMM raises RM3.2m", New Straits Times, 31 March 2011.

"Restaurant Chains to the aid of Japan", The Star, 29 March 2011.

Roy See Wei Zhi, “Malaysians Eager to Help," New Straits Times, 1 April 2011.

"Training institute donates RM4,000 to help Japan", New Straits Times, 31 March 2011.

"Ajinomoto donates RM10,000", New Straits Times, 1 April 01, 2011.

"Hotel Staff Get Busy Fundraising for Japan", The Star, 18 April 2011.

"Plan to Rebuild Facilities for Quake Victims", New Straits Times, 4 Julai 2011.
} 
managed to collect RM133,000 ${ }^{43}$ and $\mathrm{RM} 60,000^{44}$ respectively through their respective campaigns. Contributions from the campaigns Japanese Evening: In Aid of the Tsunami Relief for the Victims of the March 11 Tsunami organized by Eastin Hotel as well as an online fundraising effort by Groupon Malaysia was then channelled to the MRC and subsequently to the JRC.

Pavilion Kuala Lumpur launched The Japan Earthquake \& Tsunami Charity Fundraiser on 18 March 2011 which successfully collected RM300,000. One of the activities during the campaign was giving out speeches followed by the writing on a Card of Hope for the people of Japan. The card was then handed over to the Japanese embassy in Kuala Lumpur. Other activities included sale of t-shirts, selling of goods from Burberry, Crocs and Doris Vinci Jewellery, as well as dinner and soliciting donations. Donation boxes were also placed at the Concierge Desk on the $3 \mathrm{rd}$ floor. ${ }^{45}$ Pavilion also invited celebrities to attract attention of associations, corporations and individuals to the cause. For example, 15 Malaysian artistes took part in fundraising activities such as Raja Putri Atilia Raja Haron, actor Ryzal Jaafar, singer Amy from the massively popular rock band Search, the band Bittersweet and TV personality Belinda Chee. ${ }^{46}$ While Anuar Zain managed to garner corporate contributions totalling RM25,000 during the "secretary's week" show in Johor where proceeds from ticket sales were channeled to the Tsunami Disaster Fund through the MRC. ${ }^{47}$

The world number one badminton player (down to number two in June 2012), Lee Chong Wei managed to collect RM1 million including RM90,000 from his own pocket money in the Hope $\mathcal{E}$ Smile fundraising activities held in Penang and Bukit Kiara. Among the items auctioned during the Hope $\mathcal{E}$ Smile fundraising activities were passes to All-England matches, prized Yonex rackets used when he defeated Lin Dan in the All England championship and gold medals he won in the Malaysian Open Grand Prix. ${ }^{48}$ Former Prime Minister, Dr. Mahathir and wife Dr. Siti Hasmah also attended the fundraising activities to support Chong Wei. The shuttler also organized an exhibition match against Indonesian shuttler, Taufik Hidayat. ${ }^{49}$ Taufik Hidayat also deserves notes of appreciation for his willingness to participate in the fundraising activities. ${ }^{50}$

MRC branches of Penang and Johor also managed to accumulate significant contributions for the victims. The Johor MRC branch managed to collect RM100,200 through the contributions from various parties including RM3,000 from the Seri Alam Properties Sdn Bhd. ${ }^{51}$ Since the launch of the fund on March 14, 2011 until March 22, 2011, the accumulated total was RM1.58 million. ${ }^{52}$ While on March 31, 2011, the total

43 Jastin Ahmad Tarmizi, “Hotel Raises RM133,000 for Japan's Tsunami Victims”, The Star, 5 Julai 2011.

44 "Company Shows its Generous Side", The Star, 14 April 2011.

45 http:// promoffer2u.com/promo/pavilion-kl-japan-earthquake-tsunami-charity-fundraiser/.

46 “Artis Bantu Mangsa Tsunami, Utusan Malaysia, 8 Jun 2011.

47 "Anuar Zain 'mania' di Pusat Konvensyen Antarabangsa Persada", Utusan Malaysia, 20 April 2011.

48 “Tabung 'Hope \& Smile' Chong Wei Capai RM1j”, Utusan Malaysia, 11 Mei 2011.

49 "Dr. Mahathir Sokong Usaha Chong Wei", Utusan Malaysia, 8 May 2011.

50 “Raket Chong Wei Bernilai RM200,000", Utusan Malaysia, 4 April 2011.

51 Nabila Ahmad, "Organisations Contribute RM100,200 to Relief Fund", The Star, 21 March 2011.

52 “RM1.58m Aid for Quake Victims", New Straits Times, 22 March 2011. 
ballooned to RM3.2 million $^{53}$ and up until April 5, the MRC successfully raised RM3.95 million which would then be channeled into the JRC account. By April 19, 2011 the MRC managed to collect in excess of RM4.04 million. ${ }^{54} \mathrm{Up}$ to May 2012 the MRC delivered the balance of the fund amounting to USD2 million (RM6 million) to the JRC. The money was used to finance the construction of kindergartens and nursing school in Ishinomaki, Miyagi Prefecture.

Apart from that, the efforts by the Kelab Putera 1Malaysia should also be applauded. During a press conference on March 18, 2011, the club appealed to all Malaysians to give every possible assistance to those affected in Japan..$^{55}$ The club president, Abdul Azeez Abdul Rahim pointed out that Japan is a very close friend of Malaysia's and expressed encouragement to help to the best of our abilities. On 21 March, 10,000 fast food meals were collected by residents in Baling, Kedah. ${ }^{56}$ Meanwhile, the Melaka state government donated RM100,000 to the victims through Kelab Putera 1Malaysia. ${ }^{57}$

A total of 50 volunteers under the Kelab Putera 1Malaysia, including a medical team, media and officials from the Malaysian nuclear agency were dispatched to Japan. Ten were sent on March 26 and the rest on March 27, 2011. ${ }^{58}$ The Kelab Putera 1Malaysia envoy spent about seven days in areas most affected in Ichinomaki and Noburo in Sendai. The club also had to deal with dangerous and hazardous surroundings including exposure to nuclear radiation. ${ }^{59}$ Volunteers faced challenging situations including long journeys of up to 14 hours from Tokyo to the affected areas, very cold climate with subzero temperatures of around -5 degrees Celsius ${ }^{60}$ and aftershocks. ${ }^{61}$ They were also required to wear radiation detectors in the contaminated areas due to the Fukushima Daiichi Nuclear Power Plant disaster.

Despite these challenges, according to a member of the mission, Khairul Azwan Fauzi, volunteers were undeterred and willing to contribute their services to ensure the success of the mission. ${ }^{62}$ With the cooperation from Japanese volunteers, Kelab Putera 1Malaysia successfully delivered more than 250 tons of food, blankets, drinking water, masks, candles and health kits donated by the people of Malaysia. ${ }^{63}$

Besides the artists, the Malaysian Medical Relief Society (MERCY Malaysia) was also actively engaged in the fundraising and providing medical assistance for the victims. Immediately after the disaster, MERCY Malaysia sent a team of four evaluators to Tokyo, led by members of the executive council Dr Shalimar Abdullah to identify the needs as well as methods and avenues to channel aid to the victims. MERCY Malaysia received

\footnotetext{
“BSMM raises RM3.2m”, New Straits Times, 31 March 2011.

東日本大震災義援金、マレーシア赤新月社が集めた分が400万リンギに 19 April 2011, Mare-shia Nabi.

“Group Appeals for Japan Contribution", The Star, 19 March 2011.

"Baling Folk Donate to Victims", The Star, 21 March 2011.

“Tugas Berat Sampai Bantuan Kemanusiaan di Jepun", Utusan Malaysia, 27 Mac 2011.

"50 Volunteers to Help out Japan", New Straits Times, 25 Mac 2011.

"Sukarelawan Kelab Putera 1Malaysia Selamat Pulang dari Jepun", Utusan Malaysia, 4 April 2011.

Ibid.,

Azman Md Noor, “Wajib Pakai Alat Pengesan Radiasi”, Utusan Malaysia, 28 March 2011.

Ibid.,

63 Azman Md Noor, "Misi Bantuan di Kawasan Risiko Radiasi Tetap diTeruskan", Utusan Malaysia, 29 March 2011.
} 
cooperation from the Japanese Embassy in Kuala Lumpur, the Malaysian Embassy in Tokyo and sponsorship of tickets to Tokyo by the Malaysia Airlines (MAS) ${ }^{64}$

On March 18, 2011 the association launched the Mercy Humanitarian Fund which aimed to distribute donations to their MERCY Malaysia counterpart in Japan - the Association of Medical Doctors of Asia (AMDA), which is an international medical association based in Okayama, Japan. In terms of financial contributions, MERCY Malaysia channeled a total of USD10,000 to AMDA as immediate contribution. ${ }^{65} \mathrm{On}$ March 25, 2011 MERCY Malaysia sent a second team to support AMDA in Iwate. The assitance is part of the commitment of MERCY Malaysia as stipulated in the Letter of Undertaking (LOU) signed by both parties. Part of the commitment in the agreement was to channel funds raised in Malaysia for emergency missions under the supervision of AMDA. Another part is the dispatching of a medical team consisting of 23 doctors, 10 nurses, two midwives, one assistant nurse, two pharmacists and 24 coordinators. Malaysia Airlines once again sponsored the teams to Japan. ${ }^{66}$

In terms of funds channeled to the victims, on 15 April 2011, Symphonians United donated RM8,550 to the MERCY Malaysia fund. ${ }^{67}$ On June 1, 2011 MERCY Malaysia made a donation of RM800,000 for the purchase of medical equipments to the Minamisanriku Shizugawa Medical Clinic and Hospital in Miyagi Prefecture that was severely affected by the tsunami. Further contributions from MERCY Malaysia enabled the opening of hospital wards in the Shizugawa Medical Clinic as well as the purchase of hospital equipment such as electric beds, mattress, side table and other supplies.

In addition to the associations mentioned above, there were many other establishments which initiated relief funds for the purpose of extending help to the people of Japan. For example, Majlis Belia Malaysia (Malaysian Youth Council: MBM), set up the MBM Tsunami Humanitarian Fund which was launched by the Malaysian Minister of Youth and Sports, Shabery Cheek. The fund aimed to generate and encourage awareness amongst youths of the plight of tsunami victims. MBM also sent volunteers to clean up the worst-hit areas by the earthquake and tsunami, such as schools, community halls and playgrounds. The Young Buddhist Association of Malaysia (YBAM) also launched the Japan Earthquake E Tsunami Relief Fund to help victims. By April 16, 2011 the amount collected was RM236,720. The YBAM donation was then channeled to two international Buddha entities, the World Fellowship of Buddhists Headquarters and Buddha's Light International Association World Headquarters to ensure the funds were properly used. ${ }^{68}$

64 "MERCY Malaysia Deploys Four-Person Team to Tokyo", Visit Mercy Malaysia homepage.

65 "MERCY Malaysia signs LoU with AMDA, and Launches Japan Earthquake Relief Fund", Visit Mercy Malaysia homepage.

66 "MERCY Malaysia Deploys Second Team to Japan in Support of AMDA Relief Efforts", Visit Mercy Malaysia homepage.

${ }^{67}$ http://www.symphony.com.my/people-focus/staff-activities/mercy-malaysia-japanearthquake-and-tsunami-relief-fund-3/

68 "Handing over of YBAM-Japan Earthquake \& Tsunami Relief Fund: The Buddhist Channel", April 20, 2011. www.ybam.org.my. 


\section{Other Initiatives}

30 staff of the Universiti Malaysia Kelantan's Welfare Club organized a car wash campaign to accumulate fund for the tsunami victims. While University Kebangsaan Malaysia launched a Disaster Fund for Earthquake And Tsunami Victims In Japan on March 15, 2011 in which donation boxes were distributed to the representatives of the various faculties, institutes, residential colleges and administrators offices throughout the university. While the Department of Communication of Help University College organized a charity show to raise funds for teh japanesevictims ${ }^{69}$ The students held a concert entitled Japan, A New Dawn on June 17, 2011 which featured local celebrities like Ning Baizura, Tom Mystarz, Beat The System as well as performances by HELP students. Mosques in malaysia also took part in raising fund when the Department of Islamic Development Malaysia (Jakim) conducted fundraising projects in mosques under the Jakim administration in the Federal Territory mosques, including the National Mosque, Putra Mosque as well as Tuanku Mizan Zainal Abidin Mosque, Putrajaya. ${ }^{70}$ A total of RM117,360 was raised. ${ }^{71}$

The Ladies Association of the Embassy of Malaysia in Muscat (Muscat Representative) organized a Charity Bazaar for Japan's Tsunami and Earthquake Victims on 6 April 2011 to collect donations. Participants were the Ladies Associations of Brunei, Thailand and Indonesia. They managed to collect 907 Oman Riyal (RM7,200). The fund was then handed over to Yoshiko Morimoto, wife of the Ambassador of Japan to Oman. ${ }^{72}$

A photographer and adventurer Huey Yoong Yee, got herself acquainted with fundraising activities by selling photos taken during her 10-days journey in Tokyo, Kyoto, Osaka, Nara and Kobe entitled Japan: Celebrating Hope and Beauty. Her sentiments were expressed along the line of "I wanted to pay tribute to Japan and help its people who are in need by selling my Japanese images printed on canvas." All profits from the sale were channeled to the International Foundation of Red Crescent, which was working with the Japanese government in search and rescue as well as humanitarian work. ${ }^{73}$

In addition, the Toyota Suppliers' Club Malaysia contributed RM84,250 to the $\mathrm{JRC}^{74}$ while the Development Bank Malaysia Berhad (BPMB) contributed RM50,000 through the Japan Club in Malaysia. ${ }^{75}$ However, there are many other organizations, corporations, and individuals which contributed to the victims who are not mentioned in this article.

69 "A Fundraising Effort for Japan", HELP University Collage.

70 "Kutip Derma Bantu Jepun di Masjid", Harian Metro, 24 Mac 2011.

71 "Empat Masjid Di WP Kutip RM117,360 Bantu Mangsa Gempa Jepun", Bernama, 7 April 2011.

72 Sultanate of http://www.kln.gov.my/web/omn_muscat/e2011/-/asset_publisher/ $\mathrm{ME} 2 \mathrm{~g} / \mathrm{blog} /$ charity-bazaar-for-japan-tsunami-and-earthquake?redirect=\%2Fweb\%2Fomn muscat $\% 2$ Fe2011Oman

73 "Jade Chan, Yoong and Teoh Turn Passion into Fundraising Initiative for Japan Victims", The Star, 2 April 2011.

74 "Toyota Suppliers' Club Malaysia donates RM84k to Japan Earthquake and Tsunami fund" http:/ / blog.autoworld.com.my/index.php/2011/04/15/toyota-suppliers-club-malaysiadonates-rm84k-to-japan-earthquake-and-tsunami-fund/

75 Malaysian Development Bank, http://www.bankpembangunan.com/media/news_060411. asp. 


\section{Japanese Apreciation}

Malaysians gained much appreciation from various parties in Japan and Malaysia due to the many contributions collected. Although the value of the contributions were relatively small, but the willingness of Malaysians across the country to help out was very much appreciated. The then Japanese Ambassador to Kuala Lumpur, Masahiko Horie expressed his appreciation several times for the efforts made by Malaysians. For example, in the launch of the Girl Guides-Maybank-The Star Fund, Horie thanked the team for the effort. ${ }^{76} \mathrm{He}$ was touched by the fundraising activities organized by many parties to help the people of his country. ${ }^{77}$ In a ceremony at the University Malaysia Sabah, Horie also offered words of gratitude over the expressions of sympathy, condolences and encouragement from Malaysians given to the Japanese in the affected areas. $^{78}$

Having served three years in Malaysia and before returning to Japan on April 28, 2011, Horie repeatedly expressed his appreciation for the contributions and was touched by the kindness and sincerity of Malaysians in helping Japan. Horie also extended his thanks for the motion of condolences and sympathy by Najib Razak's speech delivered at a special session of the Malaysian Parliament. He praised the kindness exhibited by Kelab Putera 1Malaysia in their humanitarian mission and began encouraging the Japanese to "Look West and learn from Malaysia."79 All in all, the friendship shown by Malaysians to Japan when facing the eathquake and tsumani disaster was very much welcomed and appreciated. ${ }^{80}$

The succesor of Ambassador Horie, Shigeru Nakamura eaqually expressed his appreciation for the kindness having received numerous messages of sympathy, contributions and assistance from Malaysians. In one of the events at the Embassy of Japan Kuala Lumpur, Japanese school students present also expressed their appreciation for the friendship (kizuna) shown by Malaysia for earthquake and tsumani victims. ${ }^{81}$

The Kelab Putera 1Malaysia`s mission to deliver basic needs also gained appreciation from Japanese recipients. The arrival of the club members at Haneda International Airport was greeted with gratitude by young Japanese and some volunteered to participate in the mission. Some even cried and expressed their gratitude for the spirit of friendship in humanitarian missions. ${ }^{82}$ TV3 journalist, Salina Zakaria reported that the arrival of Kelab Putera 1Malaysia at the Haneda International Airport was greeted with arigato gozaimas speeches from the local community who were touched with volunteering efforts of NGOs from Malaysia. Although aid channeled might not be distributed to all the victims in Japan, yet to a certain extent, it reflects the sincere thoughts and wishes by Malaysians. ${ }^{83}$

\footnotetext{
76 "Girl Guides Launch Fund to Help Victims of Twin Disasters", The Star, 19 March 2011.

77 "Rosmah lancar Tabung Bencana Pandu Puteri bantu mangsa tsunami", Berita Harian, 18 March 2011.

78 “Jepun Ucap Terima Kasih", Utusan Malaysia, 21 March 2011.

79 "Jepun Harap Lebih Banyak Kerjasama Dengan Malaysia", Utusan Malaysia, 13 April 2011.

80 "Pavilion KL raises fund for Japan", The Star, 19 March 2011.

81 Farhana Syed Nokman, "Appreciating Bond of Friendship", New Straits Times, 28 April 2012.

82 Salina Zakaria, "Kumpulan Kedua Sukarelawan Tiba Di Tokyo Malam Tadi”, Laporan TV3, 28 March 2011.

83 Ibid.
} 
Japanese NGOs such as the Nippon Foundation and the Japanese International Food for the Hungry also praised Kelab Putera 1Malaysia for helping victims. The NGOs hoped Malaysia could continue lending a hand despite the differences in culture and language ${ }^{84}$ Many Arigato gozaimas Malaysiano speech by people in the affected area were heard upon receiving the aid. For example, a resident of Sendai, Hatsuo Watanabe, 76, a former fire brigade official remarked that food donations would be used wisely especially in facing the possibility of food shortages. Beverages received would also ease the burden due to the shortage of clean water..$^{85}$

Meanwhile, utterances of Mare-shia Doh-mo Arigato resonated amongst the people when recipients in disaster relief centers at Minoyouchu, Onagawa in Sendai received contributions. The Japanese victims were also touched by the support received from a neighbor thousands of kilometers away from their own country. ${ }^{86}$ Although still concerned about family and friends in Sendai, Japanese tourists on their way back to Japan also thanked the presence of Kelab Putera 1Malaysia team. Naoi Sato expressed her appreciation for the assistance provided.$^{87}$

A professor of International Health (Quality \& Health System) at the Tohoku University Graduate School of Medicine, Dr. Naruo Uehara, says the support of the people of Malaysia through MERCY Malaysia enabled the reopening of the hospital and extended his appreciation for the assistance received. At that particular moment they were focusing on rebuilding small clinics for people living far from hospitals and since the help from the Japanese government could not cover all their needs, the support from Malaysia and other countries was very much welcomed. ${ }^{88}$

\section{Why Kokoro to Kokoro no Kankei?}

Sympathy is a significant factor in explaining why Malaysians extended money, time and energy to help the victims. However, two important factors namely, the close relationship between both countries that dates back to $1957^{89}$ and the second factor which is the proximity and familiarity of Japanese elements in the daily lives of Malaysians such as home appliances and anime series. This familiarity compelled Malaysians to provide every assistance possible. In other words, Japan had and continues to contribute to the prosperity of Malaysia, ${ }^{90}$ especially after post independence. Moreover, the emergence

84 "NGO Jepun Puji bantuan Kemanusiaan Malaysia", Utusan Malaysia, 2 April 2011.

85 "Mohd Faizal Hassan Mangsa Tsunami Jepun Ucap 'Arigato Khozaimas Malaysiano", Bernama, 31 March 2011.

86 "Mare-shia, Doh-mo arigato Bergema di Sendai", Utusan Malaysia, 2 April 2011.

87 Salina Zakaria, "Kumpulan Kedua Sukarelawan Tiba Di Tokyo Malam Tadi", Laporan TV3, 28 March 2011.

88 "MERCY Malaysia Donates RM800,000 worth of Medical Equipment to Japan", visit MERCY Malaysia homepage.

89 Refer to Nasrudin Md Akhir, "Five Decades of Malaysia-Japan Relations," in Md Nasrudin Md Akhir, Rohayati Paidi, Japan and The Asia Pacific, Kuala Lumpur: Department of East Asian Studies, University of Malaya, 2009, pp 54.

90 Mohd Ikbal Mohd Huda, "Japanese Official Development Assistance (ODA) to Malaysia 1966-2007: Impact on the Socio-Economic Development of Malaysia" in Md Nasrudin Md Akhir, Rohayati Paidi, Mohd Ikbal Mohd Huda, Japan in East Asia: Socio Politics and Economic Dimensions, Kuala Lumpur: Japan Studies Program, University of Malaya, 2010, pp 37. 
of Japanese soft power elements transmitted through anime and other branded goods initiated the urge to mobilize efforts to help victims of the disaster in Japan. ${ }^{91}$

Najib Razak in some of his speeches stressed the status of Japan as a close friend of Malaysia since independence and the fact that when disaster struck Japan, it was time to extend help. For example, during the handover of donations to Kelab 1Malaysia ceremony, Najib reiterated the bilateral friendship and expressed gratitude for Japan`s contribution of Japan to develop Malaysia. He noted,

Japan had always been a close friend of Malaysia since her independence and this showed the people's willingness to go the extra mile to reach out to the Japanese in their time of need. Japan has been our true friend for many years. We have benefited enormously from the close ties with Japan in the form of yen loans, trade, economic development and expertise. It is only proper now in their time of need that we give our support and do all we can to help them overcome this crisis. ${ }^{92}$

Likewise when Najib Razak visited Tokyo on May 26, 2011, during his speech at the International Conference on the 17th Nikkei, again he extended Malaysia's sympathy and stressed that Kuala Lumpur is a close friend of Tokyo. Najib emphasized that the government of Malaysia is committed in helping Japan in rebuilding not only the affected areas but also its victims. ${ }^{93}$ In short, the bond between the two countries at times like these demonstrates not only possible beneficial gains as economic partners, but also a sort of camaraderie during crises and hardships.

In this regard, it is not surprising in his speech in the House of Representatives on March 16, 2011; Najib Razak called all Malaysians to give every support and assistance, be it material, emotional and moral to the Japanese victims..$^{94}$ Deputy Prime Minister, Muhyiddin Yassin echoed similar sentiments by appealing to the government and people of Malaysia to extend help to Japan and its people affected in the disaster. He argued that on previous occasions the Japanese were always ready to provide assistance to countries that needed help and this was the time for repayment. He hoped that whatever assistance extended would ease the burden of the Japanese government as well its people. ${ }^{95}$

Najib Razak identified the humanitarian mission to Japan as a sign of appreciation for the long bilateral relationship between Malaysia and Japan. The mission also served as a manifestation of the sincerity and willingness of the people in Malaysia to extend help to the Japanese who were facing great hardships due to the disaster. He reiterated that "Malaysia may be a small country but our soul is great and we are willing to come forward to help the people of Japan to cope with this stressful situation. ${ }^{96}$

In other words, the efforts shown by Malaysians recognizes that bilateral relations are significant to Malaysia in so many ways. Since the establishment of the Malaysia-

91 Interview with a student who donated to the fund at University of Malaya. She mentioned that Japan is very close to her since waching anime frequencely while she was at primary school.

92 "50 Volunteers to Help out Japan", ERA Consumer Malaysia, http://www.eraconsumer. org/eraconsumer $/$ index.php?option $=$ com_content\&view $=$ article\&id $=416: 50$-volunteers-tohelp-out-japan\&catid=39:hr-in-the-news\&Itemid=61, 25 Marcg 2011.

93 "Malaysia Sahabat Sejati Jepun: Najib", Utusan Malaysia, 26 Mei 2011.

94 Faizah Izzani Zakaria, “Takziah kepada seluruh rakyat Jepun”, Utusan Malaysia, 18 Mac 2011

95 "Tiba giliran Malaysia bantu rakyat, negara Jepun - TPM", Utusan Malaysia, 17 Mac 2011.

96 "Misi ke Jepun Bukti Keikhlasan Malaysia Bantu Rakan: PM", Bernama 23 Mac 2011. 
Japan diplomatic relations in 1957, a stable trend can be observed, one that is without any crises that might have interfered in the strength and stability of the relationship between the two countries. In fact, the relationships improved when Japan was chosen as a model for the development of Malaysia through the Look East Policy which was introduced by Mahathir Mohamad in 1982. Such policies continued during the administration of Abdullah Badawi ${ }^{97}$ and now Najib Razak..$^{98}$

In terms economic relations, since the 1970s,Japan is Malaysia^s main trading partner besides Singapore and United States. In 1970, exports to Japan was $18.3 \%$ compared to $17.5 \%$ of imports. In contrast, in 1990, Malaysia's exports to Japan recorded $15.8 \%$ compared to $24.1 \%$ of overall imports. While in 2008 imports from Japan was $10.8 \%$ versus $12.5 \%$ exports. ${ }^{99}$

From the 1960s, Japan has been a a major investor in the industrial sector. What has changed over the years is that the investment trend has shifted from that of labororiented to capital-oriented and later based on latest high technology. These investments not only resulted in employment opportunities for Malaysians but has also helped to develop the Malaysian economy. In 2004, Japanese investments in Malaysia was worth in excess of RM1,011 million, followed by RM3,672 million in 2005, RM4,412 million in 2006, RM6,523 million in 2007 and RM5,594 million in 2008. ${ }^{100}$

Japan became a major country in technology transfers to Malaysia which resulted in the birth of Malaysia's own national carmakers Proton and Perodua. In addition, in collaboration with Japan, Malaysia-Japan cooperation resulted in the establishment of Hicom, Perwaja and Pernas. Japan's involvement in the development of Malaysian economy remains active despite the possibility of transfer of Japanese investment to China and Vietnam due to lower operating costs and labour in these countries. ${ }^{101}$

Since 1966, Malaysia was among the largest recipients of the Official Development Assistance (ODA) from Japan. Until 2008, the amount of money channeled through ODA to Malaysia totaled 1.394 trillion yen. ${ }^{102}$ Aid given was divided into three types - yen loans, grants and technical assistance. The aid was for construction of basic infrastructure such as electricity, energy, water and bridges. The availability of these facilities ${ }^{103}$ encouraged foreign investors to come to Malaysia. For example, an electric power station funded by yen loans in Temenggor Dam provides $25 \%$ of electricity generated in the country. The yen loans were also used to build Temerloh Bridge, Johor Port, Pasir Gudang Port, as well as Kuala Lumpur International Airport (KLIA), which opened in 1998.

Since 1984, Japan has sponsored 30\% of Malaysian students to Japan under the Look East Policy and other assistance in the form of developing human resource skills.

97 Md Nasrudin Md Akhir, "Issues in Malaysia-Japan Relations Under the Abdullah Ahmad Badawi's Administration," dalam Md Nasrudin Md Akhir, Asmadi Hassan, Japan and East Asian Regionalism, Kuala Lumpur: Department of East Asian Studies, University of Malaya, 2008, pp 48.

98 Takashi Hoshiyama, Tetsuo Tojo, "Self-Portrait of Japan: Japan Foreign Policies Unreported by Malaysian Media", Kuala Lumpur, Japan Studies Program, University of Malaya, 2011, pp 25-30.

99 Ibid, pp 11-12.

100 Ibid, pp 19.

101 Md Nasrudin Md Akhir, "Five Decades of Malaysia-Japan Relations", pp 58.

102 Takashi Hoshiyama, Tetsuo Tojo, pp 20.

${ }^{103}$ Ibid., "Five Decades of Malaysia-Japan Relations", pp 58. 
Japan also extended aid to build the Japan-Malaysia Technical Insitute (JMTI) in Pulau Pinang in 1997 and several more projects in various universities throughout Malaysia. ${ }^{104}$ Japan also played a significant role in the sending of Malaysian students to Japan by providing teachers for Japanese language, science and other technology-related courses. between 1984 and 2010 a total of 14,000 students and trainees had been sent to Japan and after graduation, they served and continue to serve Japanese companies as well as in other private and government sectors. By sending students to Japan, relationships were built and strengthened at the individual as well as government levels respectively.

Further, again Japan came to Malaysia's aid (help was also extended to other ASEAN nations Indonesia, the Philippines and Thailand) during the Asian financial crisis in 1997. In September 1998 when the Malaysian ringgit declined by $40 \%$ against the dollar, the government ultimately pegged the currency value of RM3.80 ringgit to one United States dollar. The stock market deteriorated in September 1998 with only 262.7 points, which was a loss of RM600 billion market capitalization. Malaysia's currency controls policy received criticism from many countries, but received support from Japan. ${ }^{105}$ Japan subsequently announced the New Miyazawa Initiative for the purpose of helping Thailand, Philippines, Indonesia, Malaysia and South Korea to stabilize the regional economy. A USD30 billion aid package was submitted with USD15 billion allocated for the long and middle term needs of the financial sector and the balance of USD15 billion was allocated for short-term needs for economic recovery process. Malaysia used the yen loans for the development of Kuala Lumpur monorail project between Sentul and Batu Caves and USD2.5 billion was allocated to the Bank of Malaysia through exchange transactions between the U.S. dollar and ringgit. ${ }^{106}$

As a result of such close relations, Malaysia shifted from an aid recipient country to Japan`s strategic partner. Beginning from 2004, Japan started discussing an Economic Partner Agreement (EPA) and in July 2006 Japan-Malaysia Economic Partnership Agreement (JMEPA) ${ }^{107}$ took effect in whereby all tariffs in industrial products, agriculture and fisheries would be eliminated within 10 years. ${ }^{108}$

\section{Conclusion}

The study found that bilateral relations between Japan and Malaysia can be classified as "a friend in need is a friend indeed" in times of happiness and hardship. Malaysians were ready to help Japanese victims because of the special bond in the context of Malaysia-Japan relations, shaped by kokoro to kokoro no kankei. The close relationship which began with a diplomatic agreement in 1957 and further reinforced by the Look East Policy introduced in 1982 continues till today. Consequently, Malaysia enjoyed rapid development in economic, politics and social development. More importantly, the development of Malaysia contributed to the switch of status from an aid recipient to that of Japan's important strategic partner.

${ }^{104}$ Mohd Ikbal Mohd Huda, pp 31-66.

${ }^{105}$ Md Nasrudin Md Akhir, "Five Decades of Malaysia-Japan Relations", pp 75.

${ }^{106}$ Ibid, pp 78.

${ }^{107}$ Md Nasrudin Md Akhir, "Issues in Malaysia Japan Relations", pp 55.

108 Takashi Hoshiyama, Tetsuo Tojo, "Self -Portrait of Japan: Japan Foreign Policies Unreported by Malaysian Media”, Kuala Lumpur: Japan Studies Program, University of Malaya, 2011, pp19. 
Thus, when Japan was hit by the earthquake and tsunami, it was not surprising that all levels, Malaysians were willing to lend a hand wether in terms of financial and material aspects or energy as a form of repayment for all that the Japanese had contributed to Malaysia since independence. Although the amount contributed by Malaysians was relatively small compared to aid and contributions that was given to Malaysia, it is enough to argue that it was a contribution of kokoro to kokoro no kankei. 